\title{
USING TAX INCREMENT FINANCING TO DEVELOP AFFORDABLE HOUSING IN TORONTO.
}

by

\author{
Darrin Cohen \\ BA, University of Manitoba, 2011 \\ MA, Carleton University, 2013 \\ A Major Research Paper \\ Presented to Ryerson University \\ in partial fulfillment of the requirements for the degree of \\ Master of Planning \\ in \\ Urban Development
}

Toronto, Ontario, Canada, 2020

(C) Darrin Cohen 2020 


\section{Author's Declaration for Electronic Submission of a MRP}

I hereby declare that I am the sole author of this MRP. This is a true copy of the MRP, including any required final revisions.

I authorize Ryerson University to lend this paper to other institutions or individuals for the purpose of scholarly research.

I further authorize Ryerson University to reproduce this MRP by photocopying or by other means, in total or in part, at the request of other institutions or individuals for the purpose of scholarly research.

I understand that my MRP may be made electronically available to the public. 
USING TAX INCREMENT FINANCING TO DEVELOP AFFORDABLE HOUSING IN TORONTO

\author{
(C) Darrin Cohen, 2020 \\ Master of Planning \\ in \\ Urban Development \\ Ryerson University
}

\begin{abstract}
The City of Toronto's ten year Housing Plan established an aggressive target to develop 40,000 affordable housing units. A multitude of policies and tools will be required to achieve this goal. This paper examines the potential use of Tax Increment Financing (TIF) to help develop affordable housing units. A critical examination of Portland, Oregon and the State of Minnesota is undertaken to provide precedence for how the Province of Ontario and the City of Toronto could use TIF to achieve housing targets. This paper provides evidence to suggest TIF could be an effective tool in the City of Toronto and argues for the Province to provide regulations for its use.
\end{abstract}

Key words: Housing; Economic Development; Toronto; Tax Increment Financing; Policy 


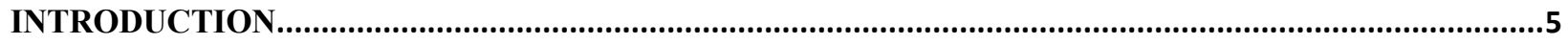

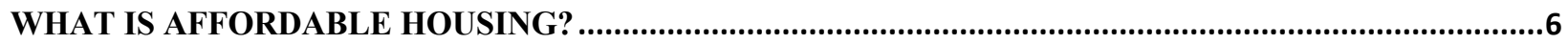

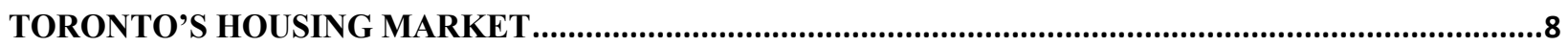

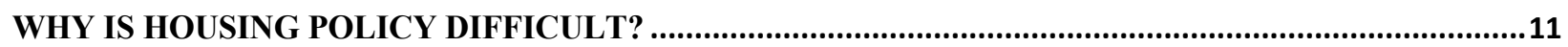

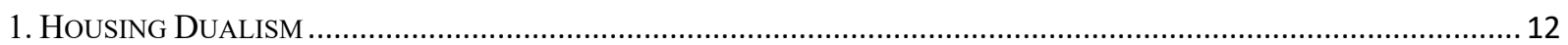

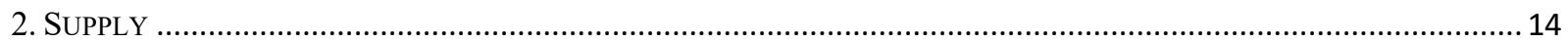

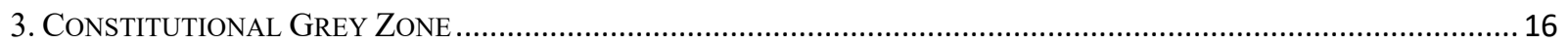

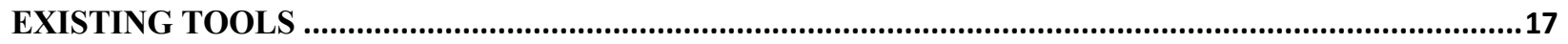

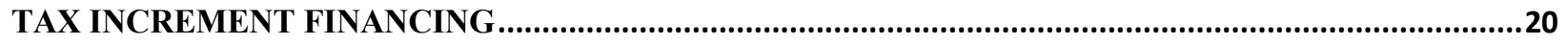

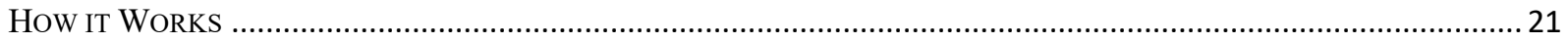

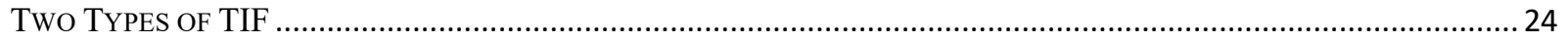

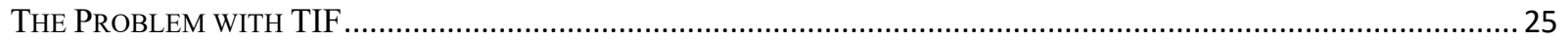

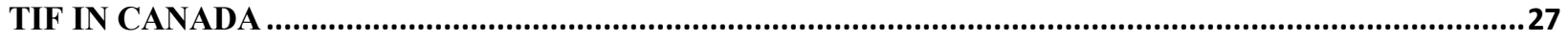

TIF FOR AFFORDABLE HOUSING ..........................................................................................................32

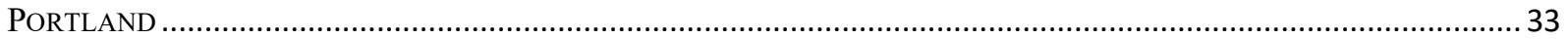

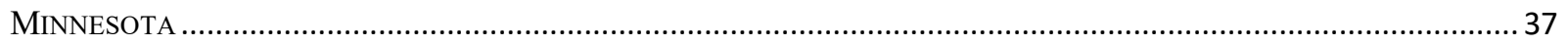

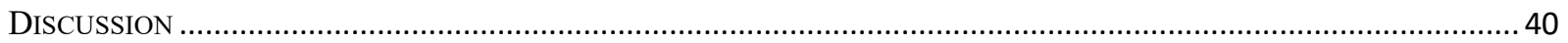

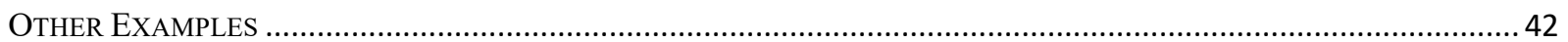

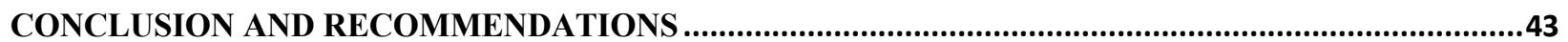

RECOMMENDATION 1: PROVIDE REGULATIONS FOR THE USE OF TIF IN ONTARIO ……............................................. 44

RECOMMENDATION 2: ENSURE TIF REGULATIONS INCLUDE MECHANISM FOR ANNUAL REPORTING TO

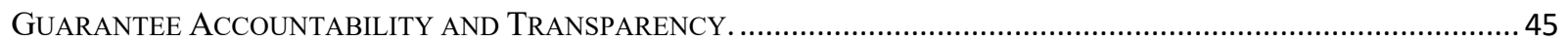

Recommendation 3: Establish Pilot TIF Project in a High Growth ARea in The City of Toronto ........ 45

REFERENCES 


\section{Introduction}

The provision of affordable housing is an important public policy issue across Canada.

Ensuring adequate housing for Canadians requires intergovernmental, private and nonprofit sector collaboration. Governments across Canada are working to increase the supply of housing and provide options for a range of tenants to reduce the burden of housing costs. Indeed, municipalities such as Toronto are facing a housing crisis and will require innovative tools to expand the housing supply and reduce costs. This paper examines Tax Increment Financing (TIF) as one potential mechanism to provide affordable housing options in the city of Toronto and argues that the use of TIF can be an effective tool to deliver affordable housing projects across the City.

The use of TIF has a long history in the United States (US) as a tool to spur economic development in areas experiencing economic decline. Over the years, TIF has evolved to include land acquisition, demolition, and public infrastructure improvements such as road reconstruction and sewer repair (CDFA 2007) and in recent years, TIF has been used to meet housing objectives. In Canada, the use of TIF is limited. In fact, only Alberta and Manitoba have TIF enabling legislation and experience with using TIF to meet economic development objectives. Ontario introduced TIF legislation in 2006, however did not release any regulations for its use. Experience in the US and Canada provide evidence that TIF could be an effective tool to spur economic development and housing projects in high cost cities such as Toronto.

This paper provides an analysis of the Canadian housing market and the challenges to developing adequate housing policy, including the dualism of housing as both an economic good and a social good and the jurisdictional challenge within the Canadian Constitution. Next, an examination of TIF and how it works provides context and background information for its 
implementation. Examples of TIF in the United States (US) and Canada and common critiques of TIF are provided to underscore how the tool works. Finally, this paper examines how TIF can be used to meet housing objectives in Toronto and provides examples of how TIF has been used to develop affordable housing projects in several cities in North America.

The analysis provided in this paper demonstrates how TIF can be used in the City of Toronto, using examples from select North American Cities, to expand the supply of housing for low- to moderate-income households if appropriate regulations are put in place. If Toronto is going to achieve its ambitious housing targets, explained below, and if the Province is serious about addressing the affordable housing crisis, new and innovative tools need to be explored. TIF may not be new in the context of North American cities, but it can be a valuable tool to mitigate the housing crisis.

\section{What is Affordable Housing?}

A well functioning and efficient housing market should be able to meet people's needs (CMHC). Unfortunately, this is not the case for many people in Toronto and in Canada. The Canadian Housing and Mortgage Corporation (CMHC) considers housing to be "affordable" if it costs less than 30 percent of a household's before-tax income (CMHC). The 2016 Canadian Census found 27.6 percent of Ontario households spend more than 30 percent of their income on housing, the highest share of households living in unaffordable housing in Canada (Amborski and Petramala 2019). This is compounded with growing wait lists for subsidized housing in Toronto $(98,000)$, Ottawa $(10,000)$, and Hamilton $(6,860)$.

According to the $\mathrm{CMHC}$, housing affordability exists along a continuum (Figure 1), ranging from government subsidized housing for households on social assistance to home ownership. All housing falls into this continuum represents a transition from the left 
homelessness and shelters) to the right (market rental and homeownership). In other words, housing policy and tools should be developed to ensure households living closer to the far left of the spectrum can transition to the far right of the spectrum. As such, each level of housing along the continuum is connected and expansion of housing on one end of the spectrum contributes to housing at the other end in that it creates more supply along the spectrum, thereby lowering prices and ensuring households can transition easily and quickly. For that to happen, housing needs to be developed at each stage across the continuum, which is why some researchers call for "the right supply in the right location" (CBI Submission on Housing 2). Similarly, households in crisis or without permanent residence will hopefully move along the spectrum with help from the government, non-profit and private housing providers.

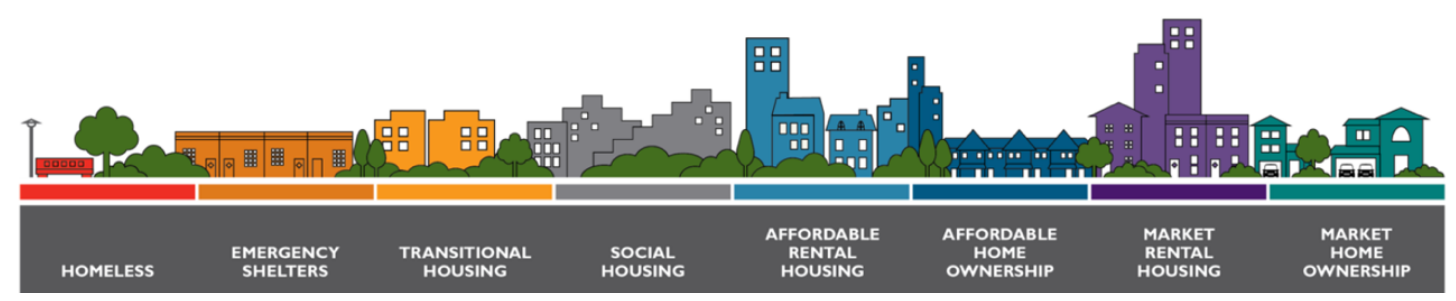

Figure 1: The Housing Continuum. Source: Canada Mortgage and Housing Corporation

According to Habitat for Humanity, "Sustainability is measured by how long a tenant should ideally be living within a space. At the beginning of the continuum, the stay is short compared to how long someone would rent an apartment (minimum one year). The continuum ends with homeownership" (Habitat for Humanity 2018). The affordable housing crisis must be understood holistically and across the full spectrum. Policy interventions designed for one part of the continuum will help every aspect of the spectrum. 


\section{Toronto's Housing Market}

The City of Toronto's housing crisis has been acknowledged by a variety of

organizations, institutions, pundits, and decision makers. According to RBC's Housing Trends and Affordability report, owning a home is still a "huge stretch" for many buyers in the Toronto market (RBC 4). This finding is reinforced by a study from the Toronto Region Board of Trade (TRBOT) which found most occupations, such as paramedics and construction workers cannot afford a home within the City of Toronto (Kalinowski). The affordability crisis goes beyond first time home buyers and extends to renters and those households relying on social housing.

Toronto's housing market is comprised of three sectors; owner, rental and social and affordable housing. These three sectors represent the full spectrum of the housing continuum explained above. In 2016, the Toronto housing market included 1,112,930 households. Of these, 587,095 (53 percent) lived in ownership housing with the remaining 524,830 (47 percent) in rental housing. Both the ownership and the rental market are experiencing supply issues and, related, affordability issues. Approximately 60 percent of the City's housing stock is comprised of housing units in apartment buildings and more than 70 percent of these units are occupied by renter households (CANCEA). Rent for condo units increased 25 percent between 2006 and 2007 while rent for new purpose-built rental units is increasing faster than median household incomes (CANCEA).

The rental sector is comprised of two parts, the primary rental market and the secondary rental market. The primary rental market consists of rental units in purpose-built apartments and row houses initiated by the private sector. The secondary markets consist of higher proportions of high- and low-cost rental housing (CANCEA 26). This section of the market is further divided into two sections: condominium rental and non-condo secondary rental housing, including secondary suites and social housing. The rental market is almost evenly divided between primary 
and secondary rental units even though the supply of purpose built-rental apartments has been declining. In 2001, primary rental made up approximately 54.5 percent of the occupied rental stock, declining to 49.1 percent by 2016 (CANCEA 23). Approximately one third of renter households reside in non-condo secondary rental housing, with the remainder in condo rental units (CANCEA 23). The number of owner households in apartment buildings has increased "as condominiums continue to be the single largest source of new housing supply in the City" (CANCEA 25). The lack of supply in purpose built rental apartments is driving the rental supply in the secondary rental market. In addition to the dwindling supply of purpose built rental, condominium rent is becoming more expensive. The prevalence of condominiums in the rental market, and the increased reliance on condominiums for the rental market, creates unsustainable, unreliable and precarious living conditions for these households. Rental tenancies in condominiums can be terminated and converted to ownership housing, removing them from the rental market altogether (CANCEA).

In the ownership sector, condominiums account for 81.5 percent of all housing completions. Between 2007 and 2017, 99.1 percent of condo completions were in high rise buildings. Further, ownership costs are outpacing median household income. Between 2006 and 2016, median owner household income declined by 15 percent while average home ownership costs grew by 60 percent (CANCEA 46). 


\begin{tabular}{|c|r|r|}
\hline Intended Market & $\begin{array}{l}\text { Number of } \\
\text { Housing } \\
\text { Completions, } \\
2007-2017\end{array}$ & $\begin{array}{l}\text { \% Housing } \\
\text { Completions, } \\
2007-2017\end{array}$ \\
\hline Total & 161,161 & $100 \%$ \\
\hline Homeowner (Freehold) & 18,119 & $11.2 \%$ \\
\hline Rental & 11,632 & $7.2 \%$ \\
\hline Condo & 131,377 & $81.5 \%$ \\
\hline Co-Op & 33 & $<0.01 \%$ \\
\hline
\end{tabular}

Figure 2: Completions by Intended Market. Source: CANCEA

Toronto's social and affordable housing stock is also experiencing challenges. Toronto is home to 72 percent of the Greater Toronto Area's (GTA) low-income single person households. In 2018, there were approximately 123,450 social and affordable rental housing units in Toronto (CANCEA). The majority of these units belong to Toronto Community Housing (TCH) and include a mix of rent-geared-to-income, affordable and market units. In 2016, the total population living in low income housing was 471,203 . This number is expected to increase by 15 percent to 542,646. By 2041, approximately 586,592 households will be low income (CANCEA). With respect to tenure, the number of low-income households living in rented dwellings will grow from 265,305 in 2016 to 297,353 in 2031 and 318,942 in 2041. Approximately 120,000 of these households will spend more than 30 percent of their income on housing and almost half will spend more than 50 percent (CANCEA). The lack of social and affordable housing in Toronto is putting pressure on the social hosing waitlist $(102,049$ households in 2019), which is expected to exceed the number of occupied spaces by 25 percent by 2031 if no new units are created (CANCEA).

The figures provided above reveal the extent of Toronto's affordable housing problem and underline the urgent need to expand the housing supply across the entire housing continuum. 
Indeed, Toronto's housing market is the second most most expensive in the country and third most expensive in North America (REF). In response, all three levels of government have provided policies and programs aimed at correcting the affordability crisis.

In December 2019, the City of Toronto approved a new 10-year Housing Plan. The Housing Opportunities Toronto Action Plan (HOT) 2020-2030 envisions a city "where housing opportunities are available for all - and where all individuals have equal opportunities to live and succeed" (HOT 1). HOT 2020-2030, which builds on the 2010-2020 plan, is an ambitious plan that seeks to create 40,000 affordable rental and supportive homes through private, public and non-profit cooperation. Further, the HOT 2010-2020 launched the Open Door for Affordable Housing Program, which provides financial incentives, capital funding and a specialized planning service to support the development of affordable rental housing in the City. The program also activates city-owned land for the development of affordable housing. Since 2016, the program has led to the approval of 6,694 affordable homes (City of Toronto). The City of Toronto announced HOT 2020-2030 with a target to create 40,000 new units. If Toronto is going to meet this ambitious target will need innovative tools and funding mechanisms. Tax Increment Financing (TIF) may be a valuable tool to increase the supply of housing.

\section{Why is Housing Policy Difficult?}

As mentioned above, it is well recognized that Toronto has a housing affordability crisis.

While there are a number of challenges and barriers to resolving the crisis, this paper highlights three important issues that need to be addressed to better understand how policy is formed in response to the crisis. The three areas include: the housing dualism of a house being an economic indicator and a social good, whether or not the housing issue is a supply issues, and the constitutional grey zone associated with housing policy. 


\section{Housing Dualism}

First, it is important to understand housing as both an economic indicator and a social good. As a social good, housing represents safety and security and is a basic necessity of life (Stone 1993; Lauster 2016). For Stone (1993), a house has deeper meaning and significance than just a physical structure. A house is "the primary setting for physiological reproduction... and a major realm in which our personality, values, and many of our social roles are defined" (13). Stone unpacks the complexity of housing by alluding to family and social relations using words such as "confusion", "love", "security" and even "violence" (13). Furthermore, he highlights the use of the term homeless not houseless when referring to people without a permanent residence and suggest that this is because their needs go "beyond physical shelter for which a 'home' is necessary, even if not sufficient" (14).

Lauster (2016) identifies four conceptual categories of a house: a concrete thing, a cultural idea, a market commodity, and a regulatory creature (12). As a physical thing, a house is something that we can see, feel, touch, smell and sometimes hear. The house as a cultural idea is one that is associated with success, adulthood and moral correctness and "acquires power by association" (14). The third category, a market commodity, refers to the house as a consumer good within the context of real estate markets. Here, the 'house' is distinct from other property types such as apartments or duplexes and becomes a commodity where "the measure of the agency possessed by a house...is usually what it costs" (14-15). Finally, Lauster suggests that the house as a regulatory creature refers to the "elaborate definitions of the house in law [that] make it distinct from other structures as a technology for dwelling" (15). Here, the house is a technical concept that influences and directs how a city is built. Stone's and Lauster's analysis demonstrate how housing is a social good, however, housing policy in Canada tends to consider housing as an economic good (Hulchanski 2004). 
As an economic good, housing is used to measure the economy and personal wealth (Alini 2018; Kirby 2019; Tencer 2018). Hulchanski rejects the notion of a Canadian housing 'sector' or 'market', arguing Canada has a housing system similar to the way Canada has a healthcare system or welfare system (225). For Hulchanski, the housing system in Canada skews towards homeownership and moderate- to high-income households through mortgage incentives and tax breaks that make it easier to buy and sell a home while the social side of the housing equilibrium is ignored or overlooked in policy discussions. Hulchanski argues, "there is simply no evidence that governments have ever intended to make progress towards a more inclusive and just housing system" (237). He brings forward the concept of a Canadian "housing system" (225) that is driven by government policy and inherently favours owners over renters. According to Hulchanski, the dualism between housing as an economic good and housing as a social good manifest in owners versus renters and decision makers tend to favour owners.

Moreover, when it comes to policy discussions about the ownership sector of the housing market, all three levels of government will bring forward policy interventions designed to help owners. This approach is reflected in August and Walks's (2018) research on the rise of Real Estate Investment Trusts (REIT) and the financialization of the housing sector. The authors' work provides further evidence to Hulchanski's claim that housing as an economic good is emphasized in government policy through the rise of REITs and other mechanisms that “decontrol rents, deregulate tenant protections, and [allow the government to] withdraw from social housing provision" (125). These provisions have resulted in the financialization of the landlord, shifting their focus away from building housing towards maximizing profits and rent. Their research suggests that this has resulted in even higher rents and housing prices and higher 
rates of evictions. The financialization of housing underscores the way in which policy makers prioritize the economic side of housing's dualism.

A house is both an economic good and a social good. Housing as an economic good favours owners and views housing as a market commodity and a tool for wealth building. Housing as a social good favours renters and lower-income families and views housing as shelter. Further, Lauster suggests that houses in the in the United States remain "eminently detachable from families", an analysis that can be applied to the Canadian context:

Today, very few people live in structures they build for themselves. Instead, people mostly purchase or rent their housing through real estate markets. Feeding those markets, builders are contracted by developers to construct on appropriately zoned lots houses they never expect to live in, according to building codes and architectural designs they had no hand in creating (15-16).

Further, when it comes to housing policies for renters and low-income families (ie, social housing), governments claim jurisdictional barriers and are largely hands-off. This dualism between owners and renters, "is helpful in understanding Canada's housing system. The dualism explains why there is political will to help one part of the housing system and not the other" (Hulchanski, 237).

\section{Supply}

The second challenge to the housing debate relates to whether or not the housing crisis is due to the lack of supply. Bean, Ellen, and O'Regan (2019) provide an excellent overview and analysis of the research that shows how building more units will lower the cost of supply. The authors find that "the preponderance of the evidence shows that restricting supply increases housing prices and that adding supply would help to make housing more affordable" (27). Advocates of the 'build more' approach often support filtering, the process "whereby the poor ultimately come to occupy what once were the homes of the rich" (Baer and Williamson 1988 
127; Rosenthal 2014). However, filtering occurs at a very slow rate and should not be part of an affordable housing strategy (Bean, Ellen, and O'Regan; Skaburskis 2006).

It is important to understand the nuance of the supply argument because affordable housing is not just about delivering more supply; it is about delivering the right kind of supply in the right places. Further, the supply argument is sometimes coopeted by the development industry as a rationale to reduce regulations (TRBOT; Wilkes, 2019; Fournier, 2019). The City Building Institute's (CBI) submission on increasing housing supply in Ontario recognizes that affordability is "the result of growing investment demand for housing and a mismatch between the type of housing end-users need and what is being delivered by the market" (1). Their list of policy recommendations includes increasing the supply of purpose-built rentals and increasing the supply of larger, family units in the urban area.

The supply argument is better understood in the context of population growth. Ontario's population is projected to grow from 14.3 million people to almost 19.8 million people by 2046 . Net migration will account for approximately 82 percent of all population growth. Further, the Greater Toronto Area (GTA) is projected to be the fastest growing region in the province, increasing from 6.8 million in 2018 to over 10.2 million in 2046. The GTA's share of provincial population is projected to rise from 47.8 percent in 2018 to 51.8 percent in 2046 (Province of

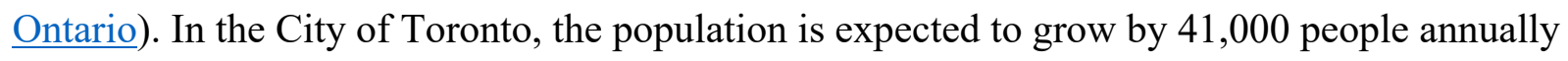
between 2016 and 2031, bringing the total population to 3,560,000 (CANCEA). Given the anticipated population growth, it is difficult to ignore the supply argument. That said, it is important to understand that not all housing supply is equal: Toronto will need to increase the supply of housing across the continuum. 


\section{Constitutional Grey Zone}

Finally, there is a constitutional grey zone with respect to housing. Section 91 and 92 of the Constitution Act, 1982 identifies federal and provincial powers and federal and provincial governments are considered autonomous and responsible for specific policy spheres. Under Section 92, municipalities are the responsibility of provinces, but the Constitution makes no mention of housing in either Section 91 or 92 . Furthermore, the right to housing is not included in the Canadian Charter of Rights and Freedom. This creates two jurisdictional issues: one, housing is not officially a human right in Canada despite the governing Liberal Party's rhetoric (See National Housing Strategy); two, no level of government is officially responsible for housing despite the fact all three levels are involved in housing.

So far, this paper has examined three challenges to housing policy. The dualism in Canadian housing policy leads to tension and often contradictory approach to policy making. Housing is both a social good and an economic good, however most policy favours the economic side. That said, there have still been a number of interventions in the housing market that recognize housing as a social good. In addition, many of the policy interventions have targeted the supply side of the housing market. As Toronto and Ontario's population continue to grow, the housing shortage will be felt across the continuum. However, it is important to ensure the right type of supply is being provided. Despite the constitutional grey zone of housing, all three levels of government have an obligation to do so and do not face significant jurisdictional barriers. 


\section{Existing Tools}

A number of tools exist to encourage the development and construction of affordable housing units in Toronto. As mentioned above, the Open Door for Affordable Housing Program led to the approval of 6,694 affordable homes since 2016. This program is part of the City's 10year housing plan and the number of affordable housing units will increase over time. The Open Door program is often used in combination with federal and provincial programs. For example, in 2020 the Federal Government announced \$200 million for affordable rental units for the Westbank led development at Mirvish Village, the former Honest Ed's site in downtown Toronto. Funding for this project comes from the National Housing Strategy's Rental Construction Financing initiative and will contribute to 366 affordable rental units (Thompson 2020). The National Housing Strategy contains a suite of complimentary programs designed to encourage the development and construction of affordable housing.

There are also several tools that exist through provincial legislation. In 2018, the Province of Ontario adopted Inclusionary Zoning (IZ) regulations to allow municipalities to introduce planning requirements for the inclusion of affordable housing in new residential developments. However, the City of Toronto did not adopt IZ policies and in 2019, the Province of Ontario, under a new government, made significant changes to the planning framework to limit the use of IZ to projects near transit stations. Schuetz, Meltzer and Been (2009) provide an analysis of inclusionary zoning policies in several American cities and some municipalities in Canada have experience using IZ. Vancouver's IZ policy requires 20 percent of units in new neighbourhoods be designated for non-market housing with at least 50 percent of the units going towards families (CPRN). Between 1988 and 2008, Vancouver's 20 percent IZ policy created 2,533 units (CPRN). However, Vancouver's IZ policy was coupled with significant federal funding, which ended in 1993, and provincial funding (CPRN). 
The City of Toronto also collects money from Section 37 of the Planning Act towards affordable housing. Section 37 allows municipalities to exchange height and density restrictions for cash with developers, allowing taller and denser buildings. This is also referred to as 'density bonusing'. For example, a recently approved building in mid-town Toronto a $\$ 5$ million Section 37 agreement, \$1.5 million of which will go towards capital improvements for new or existing Toronto Community Housing and/or affordable housing (Landau 2020). The Centre for Urban Research and Land Development argue inclusionary zoning is "effectively the same" as Section 37 because both tools rely on density bonusing (CUR 2015). However, the policies are vastly different. Inclusionary zoning requires a percentage of affordable housing units within a specific building or neighbourhood and is specifically designed for affordable housing. Section 37, on the other hand, can be used for a variety of amenities and funds dedicated for affordable housing are typically placed in a reserve fund. Regardless of the differences and similarities, the Province of Ontario amended the Planning Act and changed Section 37 requirements, however existing funds still exist, and new regulations are not fully implemented at the time of writing.

There is a growing body of literature on laneway suites and accessory dwelling units as tools for increasing the housing supply to lower prices (Mendez 2016; Mendez and Quastel 2016; Moore and McKee 2012). In 2018, Toronto approved as-of-right zoning for laneway housing in mature neighbourhoods. Laneway suites are "a specific type of detached secondary suites, which are ancillary to the principal residence and front onto a residential laneway (Race et. al., 2017, 8). The City of Toronto's has approximately 2,400 laneways that stretch over 300 kilometres throughout the city, many of which are located in dense, walkable, transit-oriented neighbourhoods (Race et, al,). Laneway housing is considered an important housing typology to increase density in, rental supply and accommodate aging in place. They can also provide 
homeowners with additional income (Race et. al. 8). The City of Toronto offers an Affordable Laneway Suites program in the form of a forgivable loan of up to $\$ 50,000$ for eligible property owners developing a laneway suite. Rent being charged for laneway suites under this program cannot exceed the City's Average market Rent, by bedroom type, for a period of 15 years (City of Toronto).

Laneway suites may not be the solution to Toronto's affordable housing crisis, but they do help increase the supply of rental housing and density in mature neighbourhoods. Similarly, Section 37 funds and IZ policies are not silver bullets for the affordable housing crisis in Toronto. Rather, these tools should be used in a complimentary fashion to encourage the development and construction of affordable housing units across the housing spectrum outlined above. These tools are also complimented by a number of demand-side policies aimed at helping families and households with the financial burden of housing, such as rent-geared-to-income and social assistance.

If Toronto is going to achieve the housing objectives outlinesd in its housing and homeless plan and if three levels of government are going to effectively tackle the housing crisis, then every available tool should be explored and utilized. Tax Increment Financing (TIF) is another tool that municipal and provincial governments have at their disposal and could be using offset housing costs. As mentioned above, TIF legislation was enacted in 2006 in Ontario but no regulations have been approved, therefore it is not in use. The following section critically examines the possibility of TIF being used to develop affordable housing units. 


\section{Tax Increment Financing}

Tax Increment Financing (TIF) is one of the most widely used financial tools in the United States (US) and has been used in almost every type of community, including central business districts, industrial neighbourhoods, small towns, suburbs and farmlands (Briffault 65). TIF was first used in California in 1952 as a method for raising money to match funds from the US Federal Urban Renewal Program. The 1949 Housing Act required municipalities with populations over 50,000 to finance one-third of the cost of redevelopment activities to match the two-thirds provided by the Federal Government (Briffault). By 1978, TIF's use dramatically increased due to the withdrawal of federal urban development funds. By 1980, there were 299 TIF areas in California and over 650 by 1990. By 1984, 28 states had approved the use of TIF, increasing to 33 states by 1987 and 44 states by 1992 (Briffault). Today, every state in the US has TIF enabling legislation except for Arizona (Briffault). One of the largest TIFs in the US is Chicago's downtown Loop District, which closed in 2008 after raising over \$1 billion over 23 years. Chicago's LaSalle Central TIF was created in 2006 and is projected to collect $\$ 2.1$ billion in revenue by 2029 (Briffault). These examples underscore TIF as a powerful tool to generate revenue. 

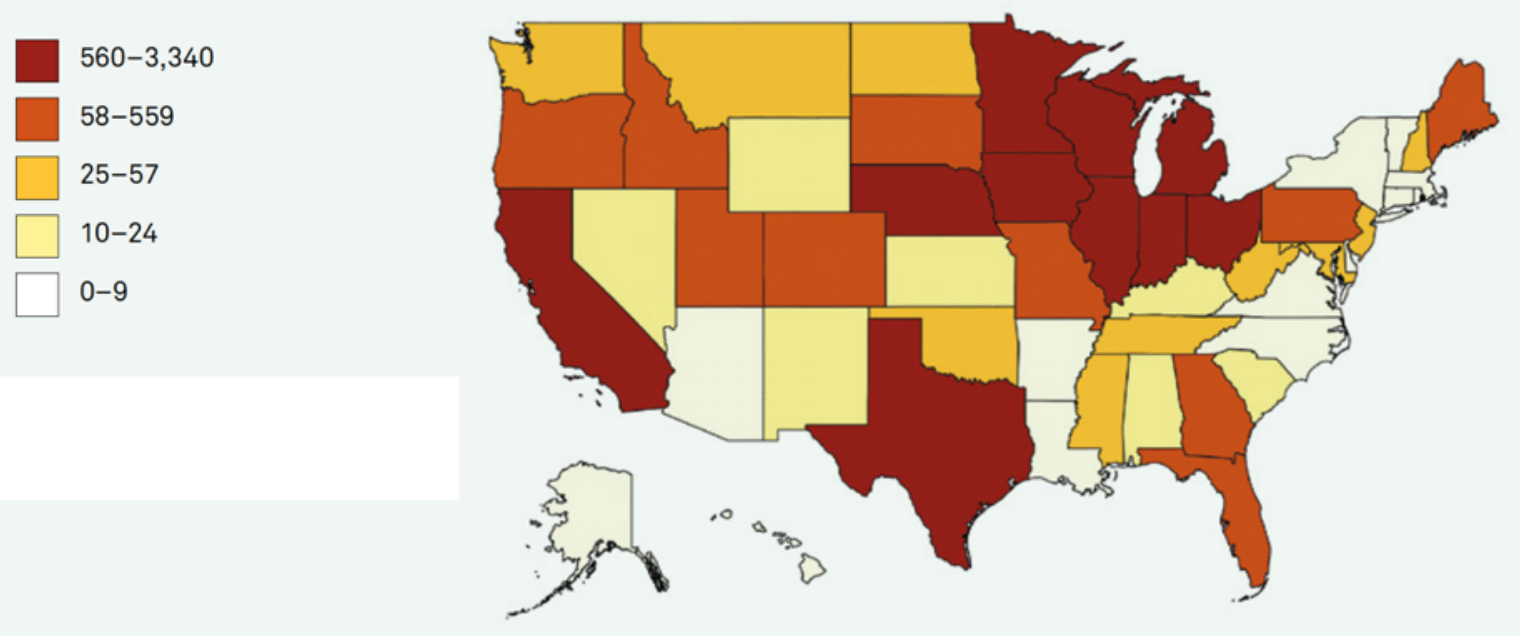

Figure 3: Estimated Number of TIF Districts in the US. Source: Merriman

\section{How it Works}

TIF is a tool that earmarks property tax revenues from anticipated increases in property values to be spent within a specific district. Despite the widespread use of TIF in the US, there is no standard formula for its use, however, there are many commonalities. The core elements of TIF include a dedicated district, a set time period for operation, expenditure that encourages economic development, and real estate appreciation that generates new tax revenues (Merriman, $6)$.

The International Council of Shoppers Centres and the Council of Development Finance Agencies developed a TIF Best Practices Reference Guide that outlines three basic steps required to use TIF: first, a TIF district's geographic boundaries are determined; second, an analysis of current property tax revenue is used to establish the base assessed value or the benchmark tax revenue and; third, local governments capture the tax increment above the initial assessed value throughout the life cycle of the district. 

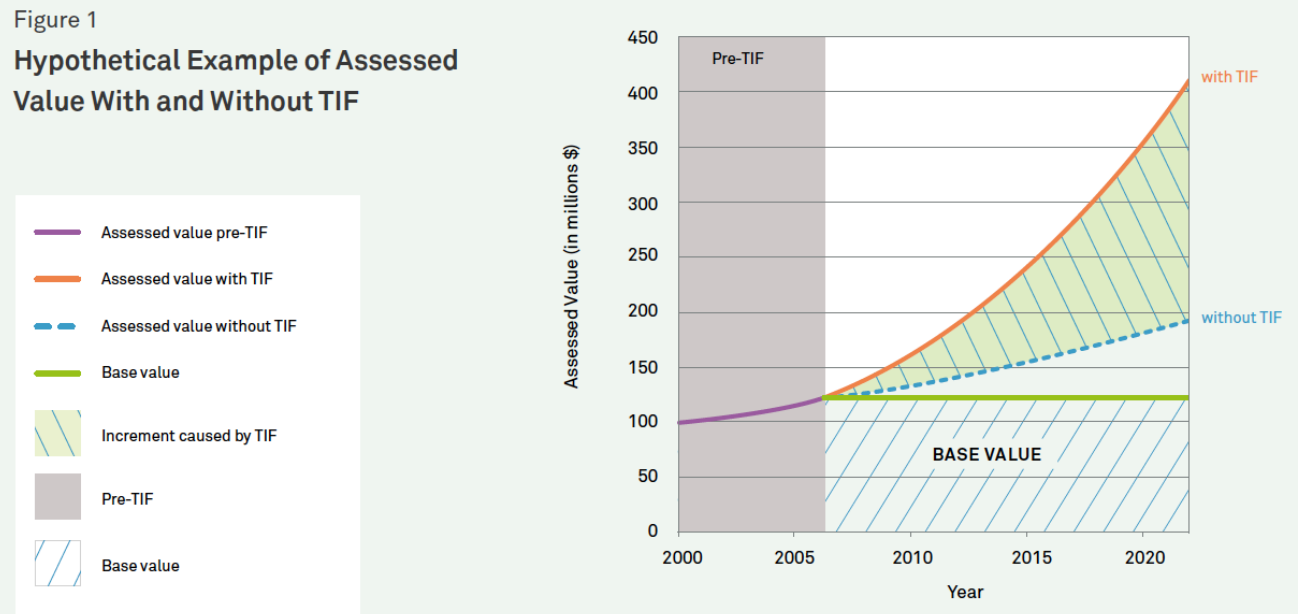

Figure 4: Hypothetical Example of Assessed Value With and Without TIF. Source: Merriman

TIF is a policy tool to capture growth in a specific geographic area. Investment in a TIF district increases property tax revenues, which are reinvested back into the district. TIF does not increase property taxes or create new taxes. It is an economic development method "designed to coordinate the actions of government and the for-profit sector" (Merriman 4). It is based on the principal that "infrastructure and public space improvements usually attract private investment and stimulate development, resulting in an increase in property taxes that could contribute to the capital cost of such intervention" (Haider and Donaldson 3)

The enabling legislation for TIF varies from state-to-state. In Minnesota, the legislation allows for six different types of TIF districts: economic development, housing, redevelopment, renewal and renovation, soil condition, and hazardous waste subdivision (Minnesota House of Representatives 2017). In Illinois, the legislation allows the use of TIF to remediate blight, conserve areas with structures older than 35 years, and promote industrial parks in areas of high unemployment (Illinois Tax Increment Redevelopment Act 2014). Further, there are a variety of ways to generate revenue flows once a district has been established. 
TIF was originally used an urban renewal tool to focus public investment in specific areas and finance infrastructure development. In some cases, new private investment occurs as soon as the district is announced in anticipation of public sector investment. In other cases, public spending occurs first to attract private sector investment to the area. In some states, TIF included federal or state matching funds or other sources of tax revenues (Merriman 8).

Despite the variation in TIF enabling legislation, almost all states require municipalities to pass two tests before establishing a TIF district:: there must be demonstrated evidence of blight and a potential TIF district must pass the "but for" test. With respect to blight, TIF originated as an economic development tool for urban areas experiencing underdevelopment. Early TIF policy focused on industrial development and residential and commercial development was later included to give local governments a degree of flexibility in their investment decisions (Smith 25). TIF was intended to spur development in blighted areas or areas experiencing economic decline and slow investment. Most TIF enabling legislation requires municipalities to provide evidence of blight even though the use of TIF has expanded. Blighted areas are considered areas that are a "menace to public health, safety, and welfare and often are defined to include defective street layouts, unsanitary conditions, and the decay of building infrastructure" (Tomme). When TIF was first implemented in 1952 it was used an economic development tool focused on reversing neighbourhood decline. Since 1952, TIF use has expanded from neighbourhood renewal to include a variety of other uses (Best Practices Guide). However, most state enabling legislation still require municipalities to provide evidence of blight despite the often-broad interpretation used to define blight (Tomme; Best Practices Guide).

The 'but for' test asks: "But for TIF, would the property have been developed?" This test ensures that TIF is used to serve the public good. If economic development would have occurred 
without the use of public funds, then the tax increment would have also occurred, and a public use would not be served. If an area would not be developed without the use of TIF then the local government will benefit from the increased property tax, which will create a public good.

Municipalities must demonstrate that a development would not occur "but for" a TIF district.

\section{Two Types of TIF}

There are two types of TIF: TIF districts and site specific or project specific TIFs. The decision to use a district or project specific TIF model depends on the scope of work and both approaches can be an effective tool for rehabilitation, redevelopment, or revitalization. However, both approaches also have drawbacks. A project specific TIF is used for a single project or property and tends to have a less complicated arrangement because it usually involves one user or property owner. Project specific TIF funds are usually used to make a project more feasible, such as infrastructure improvements or parking garages (Best Practices Guide).

\begin{tabular}{|c|c|}
\hline \multicolumn{2}{|c|}{ Pros and Cons of Project Specific TIF } \\
\hline Pros & Cons \\
\hline $\begin{array}{l}\text { - Fewer Participants } \\
\text { - Faster to establish } \\
\text { - Single property owner } \\
\text { - Less likely to involve eminent domain } \\
\text { - } \quad \text { Resources are allocated project-by- } \\
\text { project } \\
\text { - Reduced risk and financial burden } \\
\text { - Scan be a catalyst for private } \\
\text { investment in an area }\end{array}$ & $\begin{array}{l}\text { - Success relies on one user or property } \\
\text { owner } \\
\text { - Requires stronger due diligence or } \\
\text { feasibility study } \\
\text { - Smaller scale projects } \\
\text { - Repayment by one property owner can } \\
\text { create difficult credit hurdles } \\
\text { - Can be seen as an unfair development } \\
\text { advantage } \\
\text { - May fail to address underlying issues } \\
\text { in a neighbourhood }\end{array}$ \\
\hline
\end{tabular}

Source: Tax Increment Finance Best Practices Reference Guide 
TIF districts cover multiple users and property owners and tend to me more complicated arrangements. The TIF districts is used when an entire neighborhood is targeted for redevelopment. TIF district funds are typically used to support infrastructure improvements necessary for attracting private development, such as roads, traffic lights, landscaping, or parks (Best Practices Guide).

\begin{tabular}{|l|l|}
\hline \multicolumn{2}{|c|}{ Pros and Cons of District TIF } \\
\hline \multicolumn{1}{|c|}{ Pros } & \multicolumn{1}{c|}{ Cons } \\
\hline - Transformational benefits & $\bullet \quad \begin{array}{l}\text { Community opposition to } \\
\text { 'gentrification' } \\
\text { - Increases business confidence because } \\
\text { investment in a neighbourhood is } \\
\text { backed by the government partner } \\
\text { - Broad range of uses, including transit } \\
\text { infrastructure, green spaces, } \\
\text { environmental mitigation }\end{array}$ \\
- Implementation for use and \\
- Idea for land assembly \\
Can be used to attract economic \\
anchors, such as universities or \\
research facilities
\end{tabular}

Source: Tax Increment Finance Best Practices Reference Guide

\section{The Problem with TIF}

Despite the widespread use of TIF, it remains both controversial and misunderstood.

Tomme (2005) argues the current use of TIF is too lenient and enabling legislation lacks accountability and transparency. Tomme recognizes the use of TIF to relieve fiscal pressures in municipalities as state and federal funds dry up and programs and services become increasingly expensive. TIF allows municipalities to finance development without raising taxes or spending additional funds, which is politically favourable. However, Tomme warns that it has evolved in an "all-encompassing financing method for local governments and private developers" (215) and the definition of public good, prevalent in most TIF legislation, should be expanded. In addition, 
Tomme is critical of the 'but for test' suggesting it is difficult to prove that economic development would take place without a TIF.

A 2004 study of Chicago's TIF districts found that TIF policy does impact property values through increased investment (Smith 2004). The Chicago Metropolitan Area has over 400 TIF districts designed to eliminate blight, retain and attract business, develop skilled labour, stabilize the economy and stimulate job growth. The Illinois Tax Increment Allocation Redevelopment Act authorized the use of TIFs in 1977. Between 1984 and 1994, the number of TIF districts in Cook County, including Chicago and the immediate suburbs, grew from three to 155. Chicago's TIF districts range in size from three to 2000 acres and comprise approximately 19 percent of the total assessed value of real estate property in Chicago (25). That equates to over $\$ 5$ billion in property value and over $\$ 2$ billion of public investment in Chicago's TIFs (25). Using recorded sales of attached, single family properties between 1992 and 2000, Smith compared the rate of appreciation of properties and their proximity to TIF districts, taking into consideration structural factors such as neighbourhood location, and date of sale. Smith's found that "TIF designation does have a positive relationship with the market" (35).

TIF districts have also been criticized for their lack of transparency. TIF revenues are typically placed in special funds only to be used for limited purposes before the TIF district expires. There are a variety of ways to record and account for the receipt of these funds. In the best-case scenario, TIF authorities document expenditures publicly, including account balances and fund transfers. However, even in this case, the existence of a separate account not reflected in annual municipal financial reports may obscure a city's financial situation (Merriman, 2018). In less optimistic cases, funds may be misused if TIF expenditures are not well recorded. For instance, capital may be diverted for political favour or illegitimate private uses (Youngman, 
2016). A 2009 investigation in the Chicago Reader argues the City of Chicago has a "shadow budget" funded through TIF and unavailable to the public. The investigation found that TIF funds are used "to help clout-heavy developers and corporations pay for basic infrastructure and services... and strengthen the political position of the mayor" (Joravsky). In a city where a third of the property taxes is directed into special TIF accounts, transparency and public scrutiny is imperative (City Lab).

These critiques of TIF are warranted yet easily managed. The lack of transparency in some jurisdictions regarding how TIF is used can be addressed through regulations. Moreover, the lack of transparency is not inherent to TIF policy as many jurisdictions, such as Boston and Pittsburgh, have robust accounting and reporting mechanisms (ㄹeuters). TIF, like any other economic development tool or policy, has merits and drawbacks but has contributed to major infrastructure development across the US and Canada.

\section{TIF In Canada}

So far, this paper has examined the use of TIF in the United States, how it is used and why, and some common critiques against it. As mentioned above, every state except Arizona has TIF enabling legislation and, while each state is different, there are commonalities, for example, the use of TIF to combat blight and the 'but for' test. In Canada, only Alberta and Manitoba have experience using TIF. Ontario introduced TIF legislation in 2006 but did not provide regulations for its use. TIF in Alberta and Manitoba have similar development patterns as the US in terms of the criteria for its use and some of the problems. Before turning to the use of TIF for affordable housing, this paper will highlight how TIF is already being used in Canada.

Alberta was the first province in Canada to introduce TIF enabling legislation. In Alberta, a Community Revitalization Levy (CRL), the Alberta name for Tax Increment Financing, is used 
in three municipalities: one in Calgary, one in Cochrane and three in Edmonton (Government of Alberta). Similar to municipalities in the US, Alberta requires its municipalities to demonstrate that private investment would not have occurred in the absence of the CRL (the 'but for; test), the revitalization zone meets criteria for blight, and there will be enough economic growth throughout the lifespan of the CRL to cover the costs of borrowing to incentivize growth (Spahlinger and Wayne 2019). Much like TIF in the United States, investment in a CRL kickstarts economic growth, which in turn raises property values and generates higher revenues in the long-term.

The City of Calgary approved the Rivers Plan and passed the CRL Bylaw in April 2007. The CRL was established for 20 years and was the first used in Canada (Spahlinger and Wayne 2019). The Rivers Plan sought to reclaim, redevelop and revitalize the underdeveloped eastern inner-city area by encouraging high-density and mixed-use development (Spahlinger and Wayne 2019). Approximately 46 percent of the land within the district was owned by the City of Calgary, which incorporated the Calgary Municipal Land Corp. (CMLC) to implement and execute the plan.

The 2007 Rivers Plan estimates the City would need to borrow $\$ 135$ million for the initial projects in the district within the first five years. By December 2017, the City of Calgary approved \$523.5 million in projects as well as four loan bylaws totaling \$275.5 million to support the development of these projects (Spahlinger and Wayne 2019). In 2018, CMLC requested an additional $\$ 70$ million for infrastructure and outlined its top ten projects for the next ten years (Spahlinger and Wayne).

The City of Calgary made a decision not to provide detailed costs for every project within the 20-year CRL period, arguing it provides more flexibility in the plan. However, the lack of 
planning has enabled "scope creep for future unspent CRL revenue to be continually tied to new projects within the Rivers District rather than returned to the broader municipal tax base" (Spahlinger and Wayne 10). The City of Calgary estimated the CRL would generate between \$275 million and \$1.166 billion in revenues and in 2018, CMLC estimated the CRL would generate $\$ 755$ million over the CRL period (Spahlinger and Wayne 2019). Spahlinger and Wayne find that while the residential tax-base within the Rivers District grew faster than the rest of the city, it is difficult to determine if this would have happened without a CRL.

In Edmonton, CRLs have been used to finance public infrastructure in three areas: the Quarters Downtown Plan, the Belvedere Plan and the Capital Plan. The City of Edmonton approved the Downtown CRL Bylaw in 2014 to 2034. The Capital Plan outlines how the CRL will be used to mitigate risk and borrow and collect revenue. The Downtown CRL zone comprises 135 hectares of land, of which 32 percent was vacant and 20 percent underdeveloped in 2013 (Spahlinger and Wayne 2019). High construction costs and the lack of infrastructure investment deterred private sector investment in the area. Using the CRL, the City was able to build a new arena and public infrastructure. Furthermore, the City if Edmonton anticipates an increase in residential dwelling units and a doubling of downtown population (Spahlinger and Wayne 2019). Whether or not the CRL for Edmonton's Downtown plan has been successful is up for debate. Spahlinger and Wayne find mixed performance in the CRLs proforma, including a deficit in the CRL reserve fund in 2017 and 2018. However, future revenue projections show the CRL will recoup these losses. While there analysis focuses on whether or not the CRL met the 'but for' test and is in the public interest, the investment in the downtown infrastructure has been a catalyst for private sector investment and led to the development of housing and amenities. 
Another Canadian city to utilize Tax Increment Financing is Winnipeg. In 2008, the Province of Manitoba introduced the Community Revitalization Tax Increment Financing Act (Government of Manitoba) to focus on the "revitalization of Winnipeg, Brandon and other communities." The use of TIF was requested by the City of Winnipeg to support the development of the city's inland port and provide affordable housing in the downtown core. The bill allows for properties designated as "development or revitalization zones" to become eligible for TIF. The Province later amended the bill to strengthen the accountability and transparency of TIF to ensure the funds are audited and reported annually (Government of Manitoba). The Act is based on seven principles, including a clear and formal process with transparent application and criteria, minimal risk to the province, municipal alignment and collaboration, and leveraging substantial private investment and alignment with Manitoba's economic development plans. The goal is to provide clear information about TIF and ensure there is transparency and accountability measures built into its use. However, unlike US municipalities that are required to meet the "but for" test, Manitoba's Community Revitalization and Tax Increment Financing Act does not require the private sector to show a lack of funds to finance the redevelopment property. In Winnipeg, there only needs to be a "belief" that significant improvements to the property are to occur and is in the public interest that these improvements be made (Knight).

In 2017, the number of Winnipeggers in core housing need reached 12.1 percent, an increase of ten percent from 2010 (MacKinnon). Furthermore, in the downtown core, 300 units of low-cost rental housing disappeared (MacKinnon). Despite the lack affordable housing strategy by the Province and the City, Tax Increment Financing was introduced to help alleviate the pressure. The City of Winnipeg's Neighbourhood Indicators Study identifies 14 of the city's 228 neighbourhoods as Major Improvement Areas, defined as “older areas that have experienced 
significant decline to the point where housing and neighbourhood infrastructure require complete renewal" (Dessens). Five of these neighbourhoods have been designated as Housing Improvement Zones, which allows the city to access funds from the Housing Rehabilitation Investment Reserve. This reserve is intended to help address the gap between the cost of housing development and the value of the housing units. The use of these funds is akin to the "but for" test (Dessens). Plan Winnipeg 2020 Vision identifies a TIF strategy for neighbourhood revitalization and "affordable infill development" is central to the strategy (Dessens). Further, the City's Live Downtown - Rental Development Grant Program By-law requires a minimum of 10 percent of housing units subsidized through TIFs to be affordable, which means that rents would be set at or below median market rents for a minimum of five years (MacKinnon). TIF was intended to be a source of funds for the Housing Rehabilitation Investment Reserve whereby the Fund would receive the tax increment from properties that the Fund has invested in. The City has since amended the program to allow for TIF districts, which collect the tax increment from neighbouring properties (Dessens) and the by-law that required 10 percent of the funds to go towards affordable housing has since expired.

The use of TIF in Winnipeg to address affordable housing appears to be inconsistent. For example, the City has also used TIF to fund the True North Square (TNS), a $\$ 400$ million mixed use development project in Winnipeg's downtown. In 2018, the City approved an $\$ 8$ million subsidy using the City's TIF and waived the rules that require a minimum of 10 percent of the rental units to be affordable (MacKinnon). As MacKinnon writes:

The case for a comprehensive, well financed, intergovernmental strategy to address the shortage of social and affordable housing in Winnipeg has been made for several years. The use of TIF alone won't solve the problem - not a in a long shot. But TIF is one small tool that can be used to ensure affordable housing is in the mix. Despite some of the criticism of the use of TIF to develop affordable housing in Winnipeg, the policies 
that require 10 percent of TIF funds are arguably a positive step towards building and maintaining low-cost units in the city.

Winnipeg's experience with TIF is important given how the close relationship between TIF and the City's affordable housing strategy. It provides an important precedent of the use of TIF to develop affordable housing units in Toronto to help meet ambitious housing targets.

Municipalities in the US also have experience using TIF for affordable housing and this paper will examine how affordable housing has been incorporated into TIF policies. However, it is first necessary to understand what 'affordable housing' means.

\section{TIF for Affordable Housing}

This section examines two jurisdictions on the US with experience using TIF for affordable housing. The use of TIF for affordable housing helps offset the negative effects of neighbourhood revitalization because it "taps the increase in property values associated with gentrification, and spends that money on building additional affordable housing...[it] puts the funding in exactly the places where development pressure is greatest" (Cortright).

A case study methodology is used to critically examine Portland, Oregon and the State of Minnesota to understand how TIF is applied in each jurisdiction and whether or not it could be an effective tool in the City of Toronto. Portland is examined because it is considered a leader in innovative urban planning and the use TIF and the State of Oregon became the second state to authorize the use of TIF in 1958 (City of Calgary). Minnesota is examined because their legislation provides strong accountability mechanisms and clear direction for income testing. These case studies are two examples of how TIF is used for housing, however there are other states with experience using housing TIFs. 
According to Baxter and Jack (2008), the case study methodology is an effective tool that "facilitates the exploration of a phenomenon within its context using a variety of data sources" (544) to ensure an issue is understood through multiple lenses. The case study approach to research seeks to ensure topics are well covered and the object of study is revealed. Yin (2003) identifies four areas that are appropriate for case studies, of which two are relevant for this research: one, the focus of the study is to answer "how" and "why" questions; two, to uncover contextual conditions. Based on this approach, a case study method is appropriate to understand how TIF is used for affordable housing and how it can be applied to the Toronto context.

\section{Portland}

The state of Oregon has approximately 244 TIF districts (Merriman 28). In 2006, after months of public consultation, Portland City Council adopted the TIF Set Aside Policy to establish a "consistent and predictable" (Portland Housing Bureau 3) level of funding for affordable housing. Resolution No. 36404 provides policy direction to:

Dedicate a percentage of Tax Increment Financing (TIF) revenues from all Urban Renewal Districts citywide to an affordable housing set aside fund, or to create another mechanism to ensure predictable and adequate funding and prioritization of housing for individuals and families earning $80 \%$ Median Family Income (MFI) or less.

The Set Aside Policy established Income Guidelines for Urban Renewal Areas (URA) pegged at 30 percent of tax increment resources (Portland City). Further, the Income Guidelines established eligible homeowner and rental housing funding levels for the TIF for Affordable Housing resources, including homeownership opportunities for households earning up to 100 percent of the median family income. The original policy required a program review in 2010 and in 2011 when Council amended the Set Aside Policy from a 30 percent benchmark for Urban 
Renewal Areas (URA) to a 30 percent citywide benchmark. In early 2011, Council approved and adopted a set of recommendations that further improved the 30 percent Set-Aside Policy (City of Portland). Since 2015, the Portland Housing Bureau (PHB), which administers the set-aside funds and makes decisions regarding investments, has requested City Council increase the Set Aside Policy from 30 to 50 percent.

Since 2006, affordable housing investment has accounted for one third of TIF expenditures across nine URAs in Portland. In the first five years, the Set Aside Policy generated over $\$ 152$ million in housing investment (City of Portland), however TIF Set Aside policy fluctuates depending on property valuations and level of indebtedness within the individual URA. By the mid-2020, the PHB estimates annual Set Aside Revenue to settle into the $\$ 17$ to \$25 million range (CHB 9).

Portland City's TIF Set Aside Policy has not only generated almost a quarter of a billion dollars to support affordable housing since 2006, it has also supported income diversity. In the Pearl District, TIF money has supported the construction of 2,200 units of affordable housing in mixed-income projects (Cortright). Other areas in the City are using funds "to support the construction of affordable apartments and subsidize a homeownership program, with funding targeted to helping residents displaced in previous decades.

Portland City Council determines TIF Set Aside expenditure within each URA, however most funds are dedicated to creating and preserving rental housing for household earning 60 percent AMI or less. In addition, certain URAs such as the Interstate and Lents Town Centre reserve a portion of funds to assist first-time buyers and provide grants for home repairs to lowincome owners. In some cases, Set Aside Funds have been used for the acquisition of future affordable housing development (PHB 9). Between 2015 and 2019, 90 percent of all Set Aside 
policy has been spent on affordable housing for households earning 60 percent AMI and below, with the balance going towards first-time homeownership loans, community facilities serving people experiencing homelessness, and property acquisition (PHB 9).

The River District is one of the largest URAs in Portland and an example of the success of the Set Aside Policy. In 2008, Council voted to expand the River District URA into Old Town/Chinatown and parts of the central business district and created a district to build a school and community centre in outer southeast Portland. The Portland Development Council allocated \$1.6 million dollars to affordable housing, 10 percent of the district's total expenditures from TIF revenue in the first two years of the plan. This money has contributed to the Grove Apartments, which provides tenure for households earning 30 percent median family incomes or less. In addition, funding has been allocated to a number of developments for households earning 60 percent median family income or less (Street Roots 2008). In total, the program has generated \$83 million in TIF funds for 2,200 affordable housing developments in the River District URA (Cortright). The expansion of this URA and some of the developments were controversial and generated strong opposition from residents. Despite the pushback from some groups, significant money has been generated from the TIF district and invested back into the neighbourhood for affordable housing. 


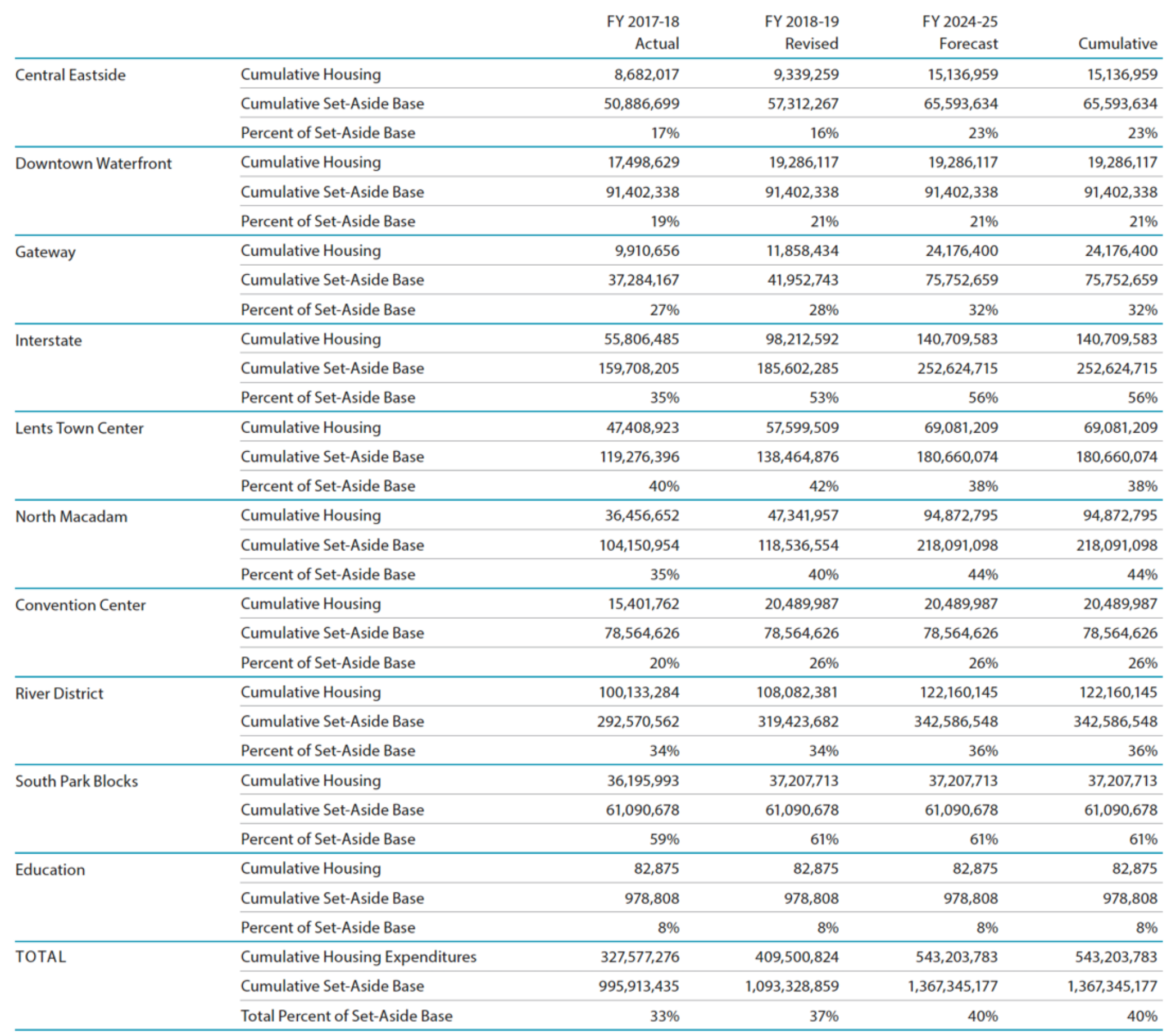

Figure 4: City of Portland TIF Revenue - Affordable Housing Set Aside (2019) 


\section{Minnesota}

The State of Minnesota allows several types of TIF districts with specific requirements for the length of time the increment may be collected, eligible sites, and how revenue generated within the district may be used. Among these include housing districts to assist low- and moderate-income housing for a maximum period of 25 years. In 2011, housing districts comprised approximately 31 percent of all TIF districts in Minneapolis. In 2016, the City of Minneapolis has 1,665 active TIF districts.

\section{TIF Districts by Type in 2016}

\section{(1,665 districts)}

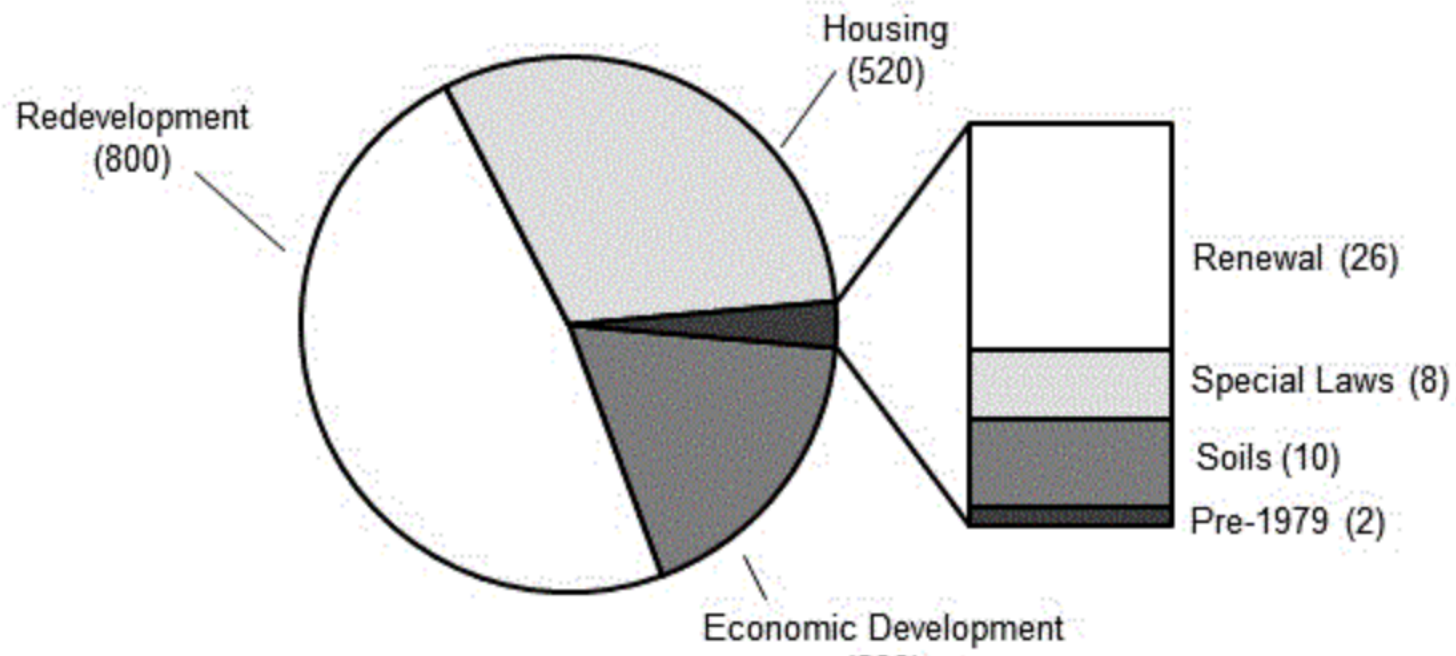

(299)

Source: 2018 Report of the State Auditor

The State of Minnesota provides direction for how a TIF is established, including reporting and accounting requirements. Major requirements for establishing a TIF include publishing notice in a newspaper, public hearings and evidence of blight and the "but for" test (Minnesota Legislature). Minnesota law allows tax increment from a housing district to be collected for 25 years, however, the authority is allowed to waive the first four years (Minnesota 
Statute) to allow the authority to "avoid using the duration limit for a year in which only a small amount of increment is received" (Minnesota Legislature).

The increment collected from a housing district can only be used to finance a housing project or public improvements directly related to the project, including administrative expenses. A housing project is defined as "a development that is intended for occupancy, in part, by lowand moderate-income individuals, as defined under a federal, state or municipal law" (Ibid). Project costs include acquisition, construction, rehabilitation, planning, engineering, architectural services and related financing costs (Ibid.). Infrastructure costs that are directly related to a project are also permitted, for example sewer and water connections for a public access road to the housing. In addition to infrastructure costs, up to 20 percent of the total square footage of improvements can be used for purposes other than housing, such as office and retail space. Alternatively, the 20 percent may be used to house individuals who do not meet the definition of low- and moderate-income.

Minnesota also requires specific income limits be satisfied in any housing project receiving TIF revenues. There are two limits, and both must be satisfied. First, the income limits under the federal, state, or municipal law that the authority uses as the legal authority for the housing project. This income limits may vary depending on the level selected by the authority. Housing units occupied by individuals who meet this income test must comprise 80 percent or more of the market value of the property in the TIF district. The second income test is the specific income limit under the applicable TIF law (Ibid.). Income limits are based on tenure. For rental housing, projects must meet one of two tests based on federal law:

1. 20-50 test: 20 percent of the units are occupied by individuals whose incomes are 50 percent or less of the area median income.

2. 40-60 test: 40 percent of the units are occupied by individuals whose incomes are 60 percent or less of the area median income. 
In some cases, the Minnesota Housing Finance Agency Challenge Program will issue a grant for a project, in which case the income limit is generally 80 percent of the applicable median (Ibid.)

In Owner occupied developments, there is a considerable higher income limit: generally, 115 percent of the greater of the area median income or the statewide median income (Ibid.) In both cases, income limits are adjusted by family size. Higher limits apply for units designed for larger families while lower limits for that of smaller families. Further, income limits may vary by county or metropolitan areas and are in place for the duration of the TIF district. Owner occupied limits apply only to the first purchaser of the unit.

\section{TIF Housing District Income Limits}

\begin{tabular}{lll}
\hline & Twin & 38 Rural \\
Cities & Counties \\
\hline
\end{tabular}

Rental Housing Developments

\begin{tabular}{|lrr|}
\hline $50 \%$ of area median (20\% required) & $\$ 45,200$ & $\$ 32,650$ \\
\hline $60 \%$ of area median (40\% required) & 54,240 & 39,180 \\
\hline
\end{tabular}

Owner-Occupied Housing

$115 \%$ of the $>$ of area or statewide

103,960

75,095

median

\section{Notes}

For family of four, effective April 14, 2017

Source: https://www.house.mn/hrd/issinfo/tif/hsgdist.aspx 
In Minnesota, TIF housing districts differ from other types of TIF districts in two ways. First, municipalities are not required to meet the "but for" test before approving a TIF district. This exemption is provided because low-income housing does not generate a large increase in market value and in some cases, a lower market value may be generated than if the site was used solely by the private market (Ibid.). The legislation considers increasing the supply of lowincome housing a greater public benefit than the expansion of the property tax base, "which lies at the heart of the market value component of the but-for test" (Ibid.)

\section{Discussion}

Both examples from Portland and Minnesota have implications for the City of Toronto. Minnesota's legislation provides guidelines for how TIF could be implemented, including eligible costs. Importantly, Minnesota's strict income tests provide examples of how 'affordable housing' could be defined in TIF legislation in Ontario. In Portland, the use of TIF for affordable housing relies on a Set Aside policy. In other words, a percentage of revenue generated within a TIF district is set aside for affordable housing purposes. Both examples could help reduce construction costs or provide low cost loans to enable affordable housing units in a development. In addition, TIF funds could be used to cover administrative cost of affordable housing, which would be particularly beneficial for a private sector housing provider that partners with a nonprofit housing provider.

In order for this to be replicated in Toronto, the Government of Ontario would need to regulate the use of TIF and establish guidelines to allow TIF districts to be used for affordable housing, either directly or through a Set Aside policy such as Portland. The City of Toronto could establish TIF districts and determine a Set Aside policy for each district. For example, Toronto has 34 Secondary Plan Areas according to Map 35 of the Official Plan. Establishing TIF 
districts along the boundaries of Secondary Plan areas could enable the City to begin collecting property tax revenue for housing projects, either within the Secondary Plan boundaries or for city-wide purposes. In addition, many Secondary Plans are identified Major Transit Station Areas (MTSA) or Urban Growth Centre's in the Provincial Growth Plan. Establishing TIF districts along these boundaries could enable both the Province and the City to achieve a number of objectives.

For example, the Yonge-Eglinton Secondary Plan aims to create complete communities in the area as it evolves and grows (Mid Town in Focus 1). The area is situated in Midtown Toronto, focused around the intersection of Yonge Street and Eglinton Avenue and extending across six square kilometres. The Secondary Plan area is generally bounded by Briar Hill Avenue and Blythwood Road to the north, Mount Pleasant Cemetery to the south, Bayview Avenue to the east, and Chaplin Crescent and Latimer Avenue to the west. The area includes the Yonge-Eglinton Centre, one of four Centres identified in the City of Toronto's Official Plan and an Urban Growth Centre in the Province of Ontario’s Growth Plan for the Greater Golden Horseshoe.

The plan identifies a number of character areas within the district and provides policy for increases growth and intensification, particularly around transit stations. This direction follows the Province's focus on Transit Oriented Development as identified in Bill 108, the More Homes, More Choice Act. Using TIF within this area could enable the City and private sector housing providers to offset construction coasts and loans to provide affordable housing options within a building. The Set Aside Policy used in Portland provides precedence and an example for the City of Toronto. In 2018, there were 5,958 residential units under review and a total of 14,567 in the pipeline, making it one of the most active and dense neighbourhoods in the City 
(City of Toronto How Does the City Grow?). The Yonge-Eglinton Centre accounted for 40 percent of all development activity in the pipeline across four Centres in 2018 and growth is expected to increase (Ibid.) In 2019, the Province of Ontario made significant changes to the Yonge-Eglington Secondary Plan to encourage increased density in the area, specifically around transit stations. Using TIF in the Secondary Plan area could capture growth and ensure the neighbourhood remains affordable and liveable.

\section{Other Examples}

As stated above, TIF is one of the most widely used financial tools in the US. Below are examples of how it has been used for the development of affordable housing. Further research is required to analyze and asses the success of these programs and policies. The City of Chicago's Multi-Family TIF Purchase Rehab Program helps private developers purchase and rehabilitate vacant and foreclosed rental buildings within designated TIF districts. The program is administered by the Community Investment Corp., a private lender, and provides assistance for 30-50 percent of the total costs needed to acquire and rehabilitee apartment buildings containing six or more specific units. Redevelopment units must remain affordable to households earning up to $50 \%$ of the area median income for at least 15 years. To be eligible, a property must be vacant and require "substantial rehabilitation", defined as rehab work that requires a permit for costs of $\$ 25,000$ or more per unit.

The State of Texas uses Tax Increment Reinvestment Zones (TIRZ) that do not need to meet any minimum criteria for blight, which allows TIF to be used in gentrifying areas where the incremental tax revenue can help preserve housing. Each taxing unit within the TIRZ may negotiate the portion of the tax increment that will be dedicated to public improvements. Private 
property owners can petition for the creation of a TIRZ when they own 50 percent of the appraised property within the TIRZ.

\section{Conclusion and Recommendations}

This paper has examined how tax increment financing can be an effective tool to provide affordable housing in the City of Toronto. Municipalities in Oregon and Minnesota have much experience using TIF to deliver housing projects and meet housing objectives. These examples provide valuable lessons for Ontario and Toronto, where TIF enabling legislation already exists. Further, this paper outlined Toronto's ambitious housing targets in the HOT 2020-2030 plan and highlighted the National Housing Strategy and the Investment in Affordable Housing Strategy as examples of how the federal and provincial government are providing incentives to expand the supply of housing. TIF should be considered as part of this expansion and legislation already exists in the Province of Ontario to enable the use of TIF in municipalities. However, as discussed above, regulations have never been provided and provincial regulators have expressed hesitation with respect to TIF regulations. At the same time, the City of Toronto's Open Door for Affordable Housing program provides relief on Development Charges and other application fees for development applications that meet specific affordable housing requirements. As such, officials at the City of Toronto may express hesitation with the use of TIF. However, this could be addressed through program design. As Toronto's population continues to grow, all available tools should be explored to provide housing options. The following recommendations are provided to address these concerns and provide direction for the use of TIF for affordable housing. 


\section{Recommendation 1: Provide Regulations for the Use of TIF In Ontario}

The Province of Ontario should provide regulations for the use of Tax Increment Financing. In 2006, the Province passed the Tax Increment Financing Act in 2006 after receiving requests from municipalities for innovative infrastructure financing tools. Regulations were never put in place due to concerns from the Ministry of Finance and the Ministry of Education regarding the potential loss of revenue. According to an official at the Ministry of Municipal Affairs and Housing:

When the Act was created, the Ontario government did not want to provide... blanket permission for TIFs across the province out of a concern for municipal finance. The size and capacity of municipalities varies considerably across the province and the government at the time was worried that it might negatively impact municipalities. Instead, the province decided that it would introduce [Tax Increment Equivalency Grants] while leaving open the possibility of TIFs in the future and only develop regulation on a case-by-case basis as requested by municipalities. When the TIF Act was created, I was also told that there was uncertainty and mixed reviews of how it has worked coming out of the US. While I think it has worked well in places, I also think there have been considerable drawbacks. ${ }^{1}$

In addition, officials in the Ministry of Finance have also expressed discomfort with the idea of diverting education and property taxes away from general coffers. While this concern has some merit, it is important to remember that TIF is a temporary diversion of tax revenue. Furthermore, examples of TIF in the United States provide ample evidence of how TIF works, when it works well and where it has been less impactful. Examples from the Provinces of Alberta and Manitoba demonstrate TIF also works in the Canadian context. If Ontario is going to make significant progress providing affordable housing units, it is important to explore all available tools.

\footnotetext{
${ }^{1}$ This data was gathered from the 2019 Advanced Studio Project, Tax Increment Financing (TIF) for Brownfield Development. The project examines the potential use of TIF for brownfield development in small- to-medium size municipalities in Ontario. The project team conducted a series of interviews with senior government officials at the Province and several municipalities, as well as brownfield practitioners and the development community. The findings from this project revealed a low level of understanding among brownfield practitioners in Ontario.
} 
Regulators need to make difficult decisions when it comes to collecting taxes and any reduction in tax revenue that results from TIF could be offset through property tax increases. As the legislation already exists, it is possible to provide regulations and grant municipalities authority to use TIF to contribute to affordable housing goals.

Recommendation 2: Ensure TIF Regulations Include Mechanism for Annual Reporting to Guarantee Accountability and Transparency.

Despite the widespread use of TIF in the United States, and the long history of using TIF for economic development, there are many examples of how TIF funds have been misused. May critics of TIF claim it created "shadow budgets" and lacks transparency and public oversight and there are many examples across the US of cases where this is true. For example, Chicago Mayor Rahm Immanuel used $\$ 55$ million of TIF revenue to renovate the Navy Pier rather than for its intended purpose of fighting urban blight (Chase and Ecker 2017). However, TIF does not inherently lead to transparency issues. Instead, misuse of TIF funds is the result of (poor) decisions made by elected officials. Robust TIF legislation must contain strong reporting and accounting measures to ensure the funds are being used for their intended purpose. Public bodies or committees with civilian participation, similar to that of a Library Board of Public Health Board, could be an effective way to guard against misusing TIF funds. Minnesota's legislation, describe in this report, provides a starting point for creating accountability measures.

\section{Recommendation 3: Establish Pilot TIF Project in a High Growth Area in The City of} Toronto

The City of Toronto should select a high growth area to use as a TIF pilot project. Chapter four of Toronto' Official Plan identifies Regeneration Areas as "unique areas of the City to a wide array of uses to help attract investment, re-use buildings, encourage new construction 
and bring life to the streets" (16). These areas are key to the City's growth strategy that mix commercial, residential, live/work, institutional and light industrial uses. In addition, the Official Plan calls for "tailor made" strategies and frameworks for development, provided through Secondary Plans. Areas identified as Regeneration Area are prime for a TIF pilot project, particularly where Secondary Plan boundaries already exist.

A common critique of TIF is that it "just spreads economic development around, rather than stimulating new growth" (Schneider 2019). However, in areas where the City is actively recruiting economic development and focusing growth, this may not be negative. If TIF simply redirects growth, then redirecting growth to a Regeneration Area will achieve an objective in the City's Official Plan. Designating a portion of TIF revenue from these areas for affordable housing will ensure that Regeneration Areas remain liveable communities. 


\section{References}

Amborski, David and Petramala, Diana. Governments in Ontario Making Headway in Using Surplus Lands for Housing. Centre for Urban Research and Land Development. April 29, 2019.

Baer, William \& Williamson, Christopher. (1988). The Filtering of Households and Housing Units. Journal of Planning Literature, Vol 3, No 2, 127-152.

Baxter, Pamela and Jack, Susan. (2008). Qualitative Case Study Methodology: Study Design and Implementation for Novice Researchers. The Qualitative Report, Volume 13 Number 4, pp. 544-559

Been, Vicki \& Ellen, Ingrid Gould \& O’Regan, Katherine (2019) Supply Skepticism: Housing Supply and Affordability, Housing Policy Debate, 29:1, 25-40, DOI:

10.1080/10511482.2018.1476899

Briffault, Richard. The Most Popular Tool: Tax Increment Financing and the Political Economy of Local Government.

BNN Bloomberg (2019). Liberal seeking to make home-buying more affordable for millenials: Morneau. January 22, 2019. https://www.bnnbloomberg.ca/liberals-seeking-to-makehome-buying-more-affordable-for-millennials-morneau1.1202159?fbclid=IwAR11KBpbXC8ChPfMBtpBJxCB4jxL9uWCZtq30DOw3NPRlfcrW q7VPmnnWEY

Carter, Tom and Polevychok, Chesya. (2004). Housing is Good Social Policy. Canadian Policy Research Network. Research Report F-50.

Canadian Mortgage and Housing Corporation. About Affordable Housing. https://www.cmhcschl.gc.ca/en/developing-and-renovating/develop-new-affordable-housing/programs-andinformation/about-affordable-housing-in-canada

Centre for Urban Research and Land Development, (2015). Is Inclusionary Zoning a Needed Tool for Providing Affordable Housing in the Greater Golden Horseshoe? (2015). Ryerson University.

Chase, John and Ecker, Danny. (2017). How City Power Players Diverted \$55 Million In BlightFighting TIF Cash To Navy Pier. Better Government Association. https://www.bettergov.org/news/how-city-power-players-diverted-55-million-in-blightfighting-tif-cash-to-navy-pier

City of Toronto Official Plan.

City of Toronto. Laneway Suites Program. https://www.toronto.ca/community- 
people/community-partners/affordable-housing-partners/laneway-suites-program/

City of Toronto (2019). How Does the City Grow? https://www.toronto.ca/city-government/dataresearch-maps/research-reports/planning-development/how-does-the-city-grow/

City of Portland. The Importance of TIF Set-Aside Policy. https://www.portlandoregon.gov/phb/article/653603

Dessens, David, Tax Increment Financing - Benefits and Opportunities. Report to Planning, Property and Development Department, Planning and Land Use Division. City of Winnipeg.

Government of Manitoba. (2008). News Releas. Innovative Tax Increment Financing Would Support Inland Port, Affordable Housing, Revitalization Initiatives: Ashton.

Government of Manitoba. (2008). News Releas. Innovative Tax Increment Financing Would Support Revitalization Initiatives: Ashton.

Habitat for Humanity. (2018). Understanding the Housing Continuum. https://habitathm.ca/understanding-the-housing-continuum/

Hertz, Daniel. City Observatory. Housing can't both be a good investment and be affordable. (2018, October 30). http://cityobservatory.org/housing-cant-be-affordable_and_be-a-goodinvestment/

Hulchanski, David J. (2002) Housing Policies for Tomorrow's Cities. Canadian Policy Research Networks Discussion Paper F-227.

Hulchanski, David J. (2004) What Factors Shape Canadian Housing Policy? The Intergovernmental Role in Canada's Housing System, in The State of the Federation 2004 Municipal-Federal-Provincial Relations in Canada, (R. Young and C. Leuprecht, eds.), Kingston: McGill-Queen's University Press, for the Queen's University Institute of Intergovernmental Relations.

Inwood, Gregory J., Carolyn M. Johns and Patricia L. O'Reilly, Intergovernmental Policy Capacity in Canada: Inside the Worlds of Finance, Environment, Trade and Health. Montreal: McGill-Queen's University Press, 2011.

Lauster, Nathanael. (2016). The Death and Life of the Single-Family House: Lessons from Vancouver on Building a Liveable City.

MacKinnon, Shauna. (2018). Fast Facts: tax increment financing and True North Square. Canadian Centre for Policy Alternatives. https://www.policyalternatives.ca/publications/commentary/fast-facts-tax-incrementfinancing-and-true-north-square 
Mendez, Pablo. "Professional experts and lay knowledge in Vancouver's accessory apartment rental market." Environment and Planning A 48.11 (2016): 2223-2238.

Mendez, Pablo, and Noah Quastel. "Subterranean commodification: Informal housing and the legalization of basement suites in Vancouver from 1928 to 2009." International Journal of Urban and Regional Research (2016).

Minnesota Legislature. Housing TIF Districts. https://www.house.mn/hrd/issinfo/tif/hsgdist.aspx

Minnesota Statutes. 469.175 Establishing, Changing Plan, Annual Accounts. https://www.revisor.mn.gov/statutes/cite/469.175

Moore, Tom, and Kim McKee. "Empowering local communities? An international review of community land trusts." Housing Studies 27.2 (2012): 280-290.

Merriman, David. (2018). Improving Tax Increment Financing (TIF) for Economic Development. Lincoln Iddnstitute of Land Policy.

Landau, Jack. (2020). Approval Recommended for Studio Gang-Designed One Delisle. Urban Toronto. https://urbantoronto.ca/news/2020/03/approval-recommended-studio-gangdesigned-one-delisle

Lauster, Nathanael, (2016). The Death and Life of the Single-Family House: Lessons from Vancouver on Building a Liveable City.

Portland Development Commission memo to Board of Commissioners. Update on the Tax Increment Financing Set Aside for Affordable Housing Policy. September 2015.

Race, Craig and Sorbara, Andrew and Sharpe, Alex and Fernandes, Ryan and Alves, Cassandra, and Francis, Mark. (2017). Laneway Suites: A New Housing Typology for Toronto. Evergreen.

RBC Housing Trends and Affordability. March 2019

Stone, Michael E. (1993) Shelter Poverty: New Ideas on Housing Affordability, Chapter 1, page13-22.

Schneider, Benjamin. (2019). CityLab University: Tax Increment Financing. https://www.citylab.com/equity/2019/10/tax-increment-financing-explained-tif-economicdevelopment/597313/

Schuetz, J., Meltzer, R., \& Been, V. (2009). 31 Flavors of Inclusionary Zoning: Comparing Policies From San Francisco, Washington, DC, and Suburban Boston. Journal of the American Planning Association, 75(4), 441-456.

https://doi.org/10.1080/01944360903146806 
Skaburskis, Andrejs. (2006). Filtering, City Change and the Supply of Low-Priced Housing in Canada. Urban Studies Vol. 43, No. 3, 533-558.

Smith, Brent. (2004) The impact of tax increment finance districts on localized real estate: evidence from Chicago's multifamily markets. Journal of Housing Economics 15 (2006) 21-37.

Street Roots. (2008). Portland's 30 percent set aside of funds for housing boasts some success, some problems and some trouble ahead. https://news.streetroots.org/2008/12/24/portland-s30-percent-set-aside-funds-housing-boasts-some-success-some-problems-and-some

Tax Increment Finance Best Practices Reference Guide (2007). The Council of Development Finance Agencies and the International Council of Shopping Centres.

Thompson, Nicole. (2020). Federal government announces \$200 million for affordable rentals at former Honest Ed's site. Toronto Star https://www.thestar.com/news/gta/2020/01/16/federal-government-announces-200-millionfor-affordable-rentals-at-honest-eds-site.html

Tomme, Alysoin. (2005). Tax Increment Financing: Public Use or Private Abuse? Minnesota Law Review, 90:213, pp 215.

Toronto Region Board of Trade. 2018 Municipal Policy Playbook: Better Housing.

UofT News. (2016). Mixed-income housing one answer for out-of-control home prices. https://www.utoronto.ca/news/mixed-income-housing-one-answer-out-control-home-prices

Wilkes, David. 2019. Op-ed: Ontario's update of development and housing plans is the right move. Toronto Star, March 2, 2019.

Yin, R. K. (2003). Case study research: Design and methods (3rd ed.). Thousand Oaks, CA:. 
